\title{
CHEMISTRY, MEDICINE, AND THE LEGITIMIZATION OF ENGLISH SPAS, 1740-1840
}

\author{
Christopher Hamlin
}

In 1951 William Addison began his history of the English spa by noting that the vast literature on the medical and chemical properties of mineral waters "would as effectively defy analysis as the waters themselves, apparently, invite it". ${ }^{1}$ Addison, like most later historians, chose to see the spa mainly as a phenomenon of social history, of changes in manners, morals, and amusements. ${ }^{2}$ Yet our neglect of those thousands of often lengthy and passionate medical and chemical treatises and pamphlets is surely unwise. ${ }^{3}$ It has left us with the impression that the success of a spa was a function of the company one found there, and that this company was utterly frivolous, little concerned with health, or disease, or with the contents of the waters, and glad to throw money at quacks whose inordinate claims and bizarre theories provided the pretence for the spa in the first place.

However well this perspective reinforces stereotypes of a Georgian world of rumpled and ruddy country squires and powdered and worldly-wise ladies, it does little to help us take such people seriously, and we are left with more questions than answers. We have no raison d'être for those many works claiming and explaining the properties of mineral waters, though in some behind-the-scenes manner those works probably vitally affected the fortunes of every spa. We have little notion of what taking the waters meant in an age in which self-diagnosis and self-treatment were far more widely accepted than they currently are and in which the bio-chemical reductionism of modern medicine had not yet become established. ${ }^{4}$ We may well be misunderstanding the role of the medical practitioner, and the relations between doctor and patient, for if the accounts of the pompous spa doctors are correct, their

Christopher Hamlin, Ph.D., Department of History, University of Notre Dame, Notre Dame, Indiana, 46556 USA.

\footnotetext{
1 William Addison, English spas, London, Batsford, 1951, p. v.

${ }^{2}$ David Gadd, Georgian summer: Bath in the eighteenth century, Bath, Adams and Dart, 1971; James Laver, The age of illusion: manners and morals, 1750-1848, London, Weidenfeld and Nicolson, 1972; G. D. H. Cole, 'Town life in the provinces', in A. S. Turberville (ed.), Johnson's England: an account of the life and manners of his age, 2 vols., Oxford, Clarendon Press, 1933, vol. 1, pp. 197-223; J. H. Plumb, Georgian delights, London, Weidenfeld and Nicolson, 1980; Roy Porter, English society in the eighteenth century, London, Allen Lane/Pelican, 1982, pp. 245-6.

${ }^{3}$ There literally are thousands. See W. H. Dalton, 'A list of works referring to British mineral and thermal waters', Report of the 52nd meeting of the B.A.A.S., 1888, London, John Murray, 1889, pp. 858-97; F. R. Peddie, A catalogue of books to 1880 , s. v. "mineral waters"; E. H. Guitard, Le prestigieux passé des eaux minerales: histoire du thermalisme et de l'hydrologie des origines à 1950, Paris, Société d'Histoire de la Pharmacie, 1951; H. Bolton, A select bibliography of chemistry, 1492-1892, Smithsonian Miscellaneous Collections \# 850, Washington DC, 1893.

${ }^{4}$ L. M. Beier, Sufferers and healers: the experience of illness in seventeenth century England, London, Routledge and Kegan Paul, 1987; Roy Porter (ed.) Patients and practitioners: lay perceptions of medicine in pre-industrial society, Cambridge University Press, 1985.
} 


\section{Christopher Hamlin}

patients must have been uncommonly gullible. Finally, we get little insight into how successful spas came to be (or why unsuccessful spas failed). We have no clue as to what combination of accessibility, amenities, claims of medical efficacy or chemical composition, and social networking was required to make a country spring into a spa.

In this paper I take up the problem of the legitimization of spas, the appeal to authority for the credentials that would persuade people to come to one spa rather than another. I shall be specifically concerned with the appeal to science, chiefly to analytical chemistry, but secondarily also with the struggle over whether chemical or clinical evidence would be the ultimate source of authority.

In the pre-modern era, legitimization of the properties of mineral waters came not from science but religion. The powers of waters have been the focus of popular faith since before recorded history, and that faith came eventually to be represented as signifying the beneficence of a pagan deity or later, a Christian saint. There were very many such holy wells, each of them an indication of the special cosmological significance of a place and of the people who lived there. During the Reformation attempts were made, often successfully, to stamp out the association of waters with saints and sometimes to close the springs themselves. ${ }^{5}$ Sometimes these attempts were founded in appeals to hard-headed rationality: those who used and believed in the springs had been duped by con men who saw an easy profit; it would be a public service to root out such superstitious gullibility by demonstrating that the waters were no different from any others. ${ }^{6}$ If only we had access to a detailed and intimate record, these transformations, from popular religiosity to institutional theology and then to science, would shed a great deal of light on the interface between popular culture and the erudite culture of the theologian, doctor, and chemist.

However those transformations were effected, by the end of the seventeenth century pamphlets and treatises on mineral waters were appealing to medical and chemical theories. Writing in 1755, Diederick Linden described his visit to Islington spa, where the proprietor "told me that he had long wished-for, and had often desired and invited gentlemen from the faculty to make Experiments, that the public, by their means, might be satisfied, that this water was a natural, and not an artificial compound." Then as now, the appeal to science was grounded in the presumption that it gave access to an objective reality. The effects of a spring whose contents and activity thus could be accounted for need no longer be tied to the fragile subjectivity of an individual patient, an advantage both to the proprietor of the spring, who then had grounds for guaranteeing the water's effects, and to the patient, who (at least if he or she accepted the naturalistic ideology that went along with science) might then have greater reason to believe the cure was real. It is not clear that the "experiments" to which Linden alluded meant much to the habitués of spas (who are usually depicted as moved more by fashion than dissolved salts). Yet it is striking that, at least in the

\footnotetext{
${ }^{5}$ André Guillerme, The age of water: the urban environment in the north of France, AD 300-1800, College Station, Texas A\&M University Press, 1988; Addison, op. cit., note 1 above, pp. 137-44.

${ }^{6}$ Reginald Lennard, 'The watering places', in Lennard (ed.), Englishmen at rest and play: some phases of English leisure, 1558-1714, Oxford, Clarendon Press, 1931, pp. 10-11.

${ }^{9}$ Diederick Wessel Linden, $A$ treatise on the origin, nature, and virtues of chalybeat waters and natural hot baths, with descriptions of the mineral waters of England and Germany, 2nd ed., London, D. Browne, 1755.
} 


\title{
The legitimization of English spas
}

early nineteenth century, cards listing the analysed constituents of spa waters were regularly distributed to patrons, ${ }^{8}$ and that almost every spa promotion was accompanied by an appeal to a scientific context, an attempt to supplement the mere claim that medical benefits existed with a medico-chemical explanation of why the water had the effects it had.

Whatever one might say about the ideal of objectivity, in the ruthlessly competitive world of spa promotion (according to Addison only one of ten spa promotions was successful), ${ }^{9}$ the vast proportion of scientific activity on mineral waters was undertaken to promote one spa or denigrate another. All too often an author's protestation that his work, unlike those of his predecessors and colleagues, would stick to the path of "science", "experiment", "sober induction", and "truth and right reason", was but an effort to sanction another commercial venture with the image of objectivity. Among many who complained about this (but practised it with authority) was the Irish physician-politician Charles Lucas, who wrote in 1756 that

\begin{abstract}
most of the voluminous and numerous tracts, and of these the most pompous ... have been published by men living and practicing upon the spot ... always interested in the fame of the particular water, which was their idol ... such a man's evidence must therefore be deemed as doubtful, concerning the efficacy of his favourite water, as that of any other priest touching the miracles of the shrine, by which he gets his daily bread. ${ }^{10}$
\end{abstract}

What view we take of these controversies is of great importance in how we come finally to understand the role of science in medicine in the eighteenth century and earlier and how we understand the rise and fall of spa medicine. Some have seen these controversies as essentially scientific, and attributed them to the difficulty of the problem of determining the effects of ingesting dilute solutions of dissolved salts. For example, N. G. Coley has written that "already by the beginning of the eighteenth century it had become clear that if mineral waters were to be used most effectively a better understanding of their chemical composition was essential." In such a view, controversy filled the space left by "confused notions... lingering alchemical theories ... [and] inadequate chemical knowledge". ${ }^{11}$

Such a view requires that we see chemistry as an independent fount of authority, in sad shape (though still accepted as relevant) through much of the seventeenth century, making great strides in the eighteenth, and becoming fully capable of dealing with problems of mineral water analysis by the early nineteenth. Here I shall suggest a different view: that mineral water chemistry was for the most part not an independent source of authority, but a product of controversy, that the relevance of chemistry was itself a controverted issue, and that the progress of chemistry does not account for a more rational assessment of spas in the nineteenth century. At issue is not whether the

${ }^{8}$ A. B. Granville, Spas of England, 2 vols., 1841, repr. with a new introduction by Geoffrey Martin, London, Adams and Dart, 1971, vol. 2, pp. 130-1, 144-5, 332.

${ }^{9}$ Addison, op. cit., note 1 above, pp. 106, 121.

${ }^{10}$ Charles Lucas, Essay on waters, London, A. Millar, 1756, 3 vols., vol. 1, p. 126.

${ }^{11}$ N. G. Coley, 'Physicians and the chemical analysis of mineral waters in eighteenth-century England', Med. Hist., 1982, 26: 123-4. 


\section{Christopher Hamlin}

work of chemists was occasioned by controversies, or even sponsored by the feuding parties, but whether we are to regard the mineral water literature primarily in terms of intellectual history or in terms of the history of the exploitation of popular notions of health (or, whether we find a perspective that blends these categories). ${ }^{12}$ If the controversies in which chemists took part were ultimately fuelled by economic competition, then better chemistry would not have resolved them. Yet we still need to explore how it was that chemistry could contribute to them at all, and it is here that the issue of the relevance of reductionistic explanation comes in. The theme that arises repeatedly in the mineral water literature is the conflict between two kinds of evidence; alleged cures on the one hand and alleged contents of waters that could account for these on the other. It was a context in which much of the chemistry done was done in the service of vested interests, yet one which was also scientifically progressive, for (at least until the 1830s) it denied the chemists the luxury of a paradise of normal science in which their most fundamental assumptions of the relevance of chemistry might be spared from constructive criticism.

If one takes "analysis" and "chemists" in a loose sense, chemists had been judging waters against a common standard since the time of Aristotle. ${ }^{13}$ Yet for much of that period they were operating under assumptions about the substantial nature of the natural world quite different from those we now hold. For example, while banishment of the saints left room for signification from chemistry, during the golden age of the chemical philosophy (roughly 1570 to 1650 ), the sorts of claims made on behalf of waters changed less drastically than one might expect. Even though chemists could classify a water as belonging to one of a small number of classes of mineral waters, the ruling images of an animate cosmos in which all things affected all other things and of an earth in which the vital processes were birth, regeneration, and death, combined to give plausibility to the view that the medicinal properties of any spring were unique, irreducible, and inimitable. ${ }^{14}$

Even throughout the first half of the eighteenth century these "hand of nature" explanations were likely to be made both by chemists and by medical practitioners. Prior to the development of pneumatic chemistry such a view was made even more plausible by chemists' inability to deal with the dissolved gases that in the cases of many of the waters accounted for the most intriguing properties-their taste, texture, and odour. When stored these waters lost their special qualities; they went flat. ${ }^{15}$ Such properties could not be understood by conceiving of a water as an element or a

\footnotetext{
${ }^{12}$ Compare the views of Coley, Addison, and Harley on one of the first of these pamphlet wars, over the properties of the Scarborough waters (cf. N. G. Coley, "Cures without care: "Chemical Physicians" and mineral waters in seventeenth-century English medicine', Med. Hist., 1979, 23: 200; Addison, op. cit., note 1 above, p. 102; D. Harley, 'Religious and professional interests in the northern spa literature, 1625-1775', Bull. Soc. social Hist. Med., 1984, 35: 14-15.) For Coley, science is primary, for Addison it is only the means for pursuing what is basically a commercial rivalry between Knaresborough and Scarborough.

13 Allen Debus, 'Solution analyses prior to Robert Boyle', Chymia, 1962, 8: 41-61; idem, 'Fire analysis and the elements in the sixteenth and seventeenth centuries', Ann. Sci., 1967, 23: 127-47.

${ }^{14}$ Idem, The chemical philosophy, 2 vols., New York, Science History, 1977; Yi-Fu Tuan, The hydrologic cycle and the wisdom of God: a theme in geoteleology, University of Toronto Press, 1968; Carolyn Merchant, The death of nature: women, ecology, and the scientific revolution, London, Wildwood House, 1982.

15 William Saunders, A treatise on the chemical history and medical powers of some of the most celebrated mineral waters, with practical remarks for the aqueous regimen, London, Phillips, 1800, p. 22.
} 


\section{The legitimization of English spas}

chemical compound, both of these concepts being anachronistic for the period. Instead, waters were conceived as a complicated and changing mixture including a watery principle, various dissolved and suspended salts and earths, and a spirit, the "life" or "soul" of the water as it was called, that transcended analysis or capture. ${ }^{16}$ Hence for these reasons it was quite easy to see springs as part of the living bounty of nature; they were gifts we could use, but which we could never recreate or analyse: we would, as it were, "murder to dissect". Even with the coming of the mechanical philosophy these key claims of pharmacological uniqueness, irreducibility, and inimitability could still be sustained, for corpuscularianism provided no firm grounds for limiting the range of medicinal properties a water might be conceived to possess. ${ }^{17}$

This view, expounded most influentially by the famous German physician Friedrich Hoffmann, had implications for the commercial side of the spa business. To drink living water was possible only at the spring; bottled versions (or imitations), which were available for export, tended to be looked upon (doubtless justifiably in many instances) as inferior versions of the real thing. Similarly, the medical men who attended at spas argued that the waters, to be medically effective, had to be taken as part of a complete spa regimen, a view that was given greater credence by the view that both illness and health were jointly matters of mind and body, and that the amenities of the spa-scenery, food, peace, amusement-were as much part of the effect as were the material effects of the waters. William Saunders, who was not a partisan of a particular mineral water, wrote in 1800 that,

it is merely advantage of situation or accidental causes that have given some of these a superior reputation over the rest; and where this is owing to beauty of site or local conveniences, it is well merited, as these circumstances have no small share in the general plan of care, by enabling the invalid to employ daily exercise, and giving that irresistible charm to the spirits, which the site of a beautiful or romantic country almost always excites. ${ }^{18}$

What should be clear about both these claims is that they were not readily falsifiable; without much more precise definitions of disease and very sophisticated techniques for conducting clinical trials, techniques which barely exist today, there was no basis for comparing the effects of treatment and deciding whether or not claims of uniqueness were warranted. What appeals to experiment were made were likely to be extraordinarily simplistic. Frederick Slare compared the waters of Spa and Pyrmont by drinking first one, then the other, each for a week, and then drinking them alternately for 20 days: "the result was so plain and manifest to me that the Pyrmont waters gave me more Spirit and Strength those days I drank them, than when I used the others." 19

At least for chemists, the most important factor in removing mineral waters from the realm of the living was the development of pneumatic chemistry in the

${ }^{16}$ Ibid., pp. 4-5.

${ }^{17}$ Linden, op. cit., note 7 above, p. 6.

${ }^{18}$ Saunders, op. cit., note 15 above, p. 254. See also Lennard, op. cit., note 6 above, p. 14; P. J. Neville Havins, The spas of England, London, Robert Hale, p. 132.

${ }^{19}$ Frederick Slare, An account of the Pyrmont waters dedicated to Sir Isaac Newton, [London?], 1717, pp. 2-3. 


\section{Christopher Hamlin}

mid-eighteenth century. Henceforth there would be reason to believe that not only the salts, metals, earths, and aqueous parts could be distinguished, but also the gaseous essence; in other words, that the water could be completely accounted for as a collection of isolatable components. ${ }^{20}$ Increasingly there were three uses of this understanding: in the promotion of new springs, in the de-bunking of old springs, and in the imitation of the waters of famous springs. None of these uses was new, but the new chemistry did threaten the equilibrium of charges and rebuttals by representing a neutral and common standard against which claims could be evaluated. If waters could only have effects in consequence of their constituents, chemists could claim that they alone could detect medical fraud. Analysis likewise could quickly vindicate claims made on behalf of under-utilized springs with no tradition of testimonials and custom to support them. Finally, understanding the effects of a mineral water in terms of its composition would allow it to be imitated, or even improved. The pneumatic chemistry therefore did much for the authority of chemists, who had a much stonger basis for saying that they had rightful control over legitimization.

In fact, however important the pneumatic chemistry may seem to us in retrospect, its coming did not compel the giving up of "hand of nature" arguments. Physicians continued to argue that clinical facts overrode the claims of chemists. Compositional chemistry was far too feeble an instrument to discover either the true nature of a mineral water or the complicated relations between the water, the circumstances of taking it, and the individual's constitution that together accounted for medical effectiveness.

We can see the shape of this debate by contrasting the views of two authors, the Swedish chemist Torbern Bergman and the Cheltenham doctor John Barker, writing within a decade of one another, Bergman in the late 1770s and Barker in 1781. Of the two Bergman is certainly the better known; he was the most prominent Swedish chemist of his day and the originator of what became the standard method of mineral water analysis between about 1780 and 1830. His Physical and chemical essays (English translation, 1784) included several treatises on mineral water chemistry, and for English chemists of the early nineteenth century Bergman symbolized the transition from obscurity to order in this field; prior work belonged to the "regions of hypothesis and fancy".21

Bergman ridiculed Hoffmann's claims of inimitability: "it can be of little consequence whether the water dispersed through the bowels of the earth, [and] by passing through certain strata extract certain materials, or whether those very artificial materials be artificially added in proper quantity: the hand that supplies the ingredients can make no difference in the results." 22 Opposition to these artificials

\footnotetext{
${ }^{20}$ Coley, op. cit., note 11 above, pp. 129-32; J. B. Gough, 'Lavoisier and the fulfillment of the Stahlian revolution', Osiris, 2nd ser., 1988, 4: 15-33; Uno Boklund, 'Torbern Bergman as a pioneer in the domain of mineral waters', in T. Bergman, On acid of air, Stockholm, Almqvist and Wiksell, 1956, pp. $105-28$.

${ }_{21}$ Thomas Garnett, $A$ treatise on the mineral waters of Harrowgate containing the history of those waters, their chemical analysis, medicinal properties, and plain directions for use, 4th ed., Leeds, Edward Baines, 1804, p. 15; Thomas Thomson, The history of chemistry, 2 vols., London, H. Colburn and R. Bentley, 1831, vol. 2 , p. 41

${ }^{22} \mathrm{~T}$. Bergman, 'On the preparation of cold medicated waters', in Physical and chemical essays, transl. E. Cullen, London, John Murray, 1784, vol. 1, pp. 263-74.
} 


\section{The legitimization of English spas}

would come from those who simply feared novelty, from those who truly believed in inimitability, and from those "who prescribe and sell foreign waters" ${ }^{23}$ Bergman also argued that analysis was the quickest, if not the only adequate means of comparison among springs. If a newly-discovered spring were found to possess the same components as one long used and whose medical properties were well known, practitioners could immediately begin dispensing the new water on the basis of experience accumulated from the old. ${ }^{24}$ Likewise, by determining the differing effects of springs with different compositions, one could work out the pharmacological properties of each of the different components. In either case, one made pharmacological inferences from chemical facts, and pharmacological possibility was therefore reducible to chemistry.

For John Barker all this was hasty and simplistic. Barker wrote on behalf of Cheltenham, which was just then blossoming into its full glory as a spa: George III made a lengthy and highly successful visit to the spa the same year that Barker's Treatise on Cheltenham Water and its great use in the present pestilential constitution appeared. Full of praise for the views of Friedrich Hoffmann, he made much of the difficulty, indeed the impossibility, of ever coming to know the make-up of mineral waters, such a claim being but "the crude conception and immature production of a deluded mind". ${ }^{25}$ Barker did not reject chemistry out of hand-"a good servant to physic, though a very bad master"-yet neither did he see any use for analysis. It was suited only to "ascertaining the grosser contents of waters", which were usually evident from taste, odour, and physiological effects anyway. But it was the more "subtle medium" that was responsible for "their exquisite nature". ${ }^{26}$ What Barker sought was some kind of integrated knowledge of mineral waters in which the experienced physician, having access to all the facts-those of water composition, season, condition of the patient, etc.-would render a judgement that would be irreducible to any algorithm and on which detectable chemical constituents would have only a limited influence.

Barker's position may seem as wilfully obscurantist as Bergman's is resolutely empirical. Yet Barker too was able to place himself rhetorically as one of the rational moderns. He treated the chemists as belonging to the past age of "imperfect systems". They were the over-simplifiers, "full of the parade of learning ... little minds not able to take in the whole that relates to the subject."27 Failure to use mineral waters properly in the past had been a product of such blind medical dogma, which was only beginning to yield to "strict attention, observation, and reason" with regard to the causes of disease.

There were in fact good arguments on both sides, and we may recognize how similar the controversy was to the modern debate between proponents of holistic concepts of health and defenders of a biochemical-pharmacological reductionism.

\footnotetext{
23 Ibid., p. 276.

24 Bergman, 'Treatise on Bitter, Seltzer, Spa, and Pyrmont Waters and their synthetical preparation', transl. Sven M. Jonsson, in T. Bergman, op. cit., note 20 above, p. 32.

${ }^{25}$ John Barker, A treatise on Cheltenham water and its great use in the present pestilential constitution, Birmingham, Pearson, 1786, p. 6.

${ }^{26}$ Ibid., pp. 4-5.

27 Ibid., pp. 31, 2
} 


\section{Christopher Hamlin}

But whatever one may say about the modern debate, in the eighteenth century the disputes between the followers of Bergman and those of Hoffmann was not primarily a conflict over philosophies of health or even disciplinary priority. It was, instead, a struggle to uphold or establish the reputations of individual springs. Thus it was not a matter of doctors versus chemists, but of some doctors versus some chemists (and frequently of chemists against chemists and of doctors against doctors). Promoters of springs were usually willing to seek out the good news wherever it could be found; they sold their wares through descriptions of scenery and accommodations, appeals to medical theory, testimonials and case histories, and analyses of contents.

Increasingly, however, in cases where medical testimony was pitted against chemical analyses, chemistry triumphed. By the end of the first decade of the nineteenth century, the old "hand of nature" arguments were no longer much used. Writing in 1841 , Granville attested to the primacy of chemistry:

even the well-tested effect of such [Scarborough] waters will not prove sufficient to fix permanently the opinion and favour of the public in their behalf, if medical men of influence and character, practising on the spot, publish, from time to time, an account or analysis of their component parts ... which differs from that of its predecessor. ${ }^{28}$

This transformation is exactly what we might expect, given what we know of the success of the Lavoisierian revolution. Yet it is likely that the triumph of chemistry owed less to the maturation of analytical technique than to growing faith that chemistry was the proper authority. Indeed, all the while chemists were successfully claiming the authority to pronounce upon the properties of mineral waters, chemistry itself was being shaken by internal developments that suggested both that water analysis was intellectually fraudulent and that perhaps the defiant doctors had been right after all. After Bergman, the problem of how to understand waters whose apparent medicinal effects could not be explained in terms of their apparent chemical composition continued to fester. Chemists, including Bergman, had long recognized such cases and had come up with various ad hoc explanations to account for them. The physical state of the matter was often held to be of great importance; the fineness of the particles, and their corresponding ability to spread far throughout the body might explain how a water could have far greater effects than its analysis appeared to permit. With such a tactic chemists could continue to insist that effects could be reduced to the constituents they could detect, even if the effects of a given constituent varied so greatly that they could mangle any set of analytical findings into consistency with any claims of medical effects. ${ }^{29}$

Beyond this problem, chemists also found themselves unable to agree on exactly what the composition of certain waters was. They differed not only over the quantities of particular salts and earths in the water of a particular spring, but even over the identity of the materials dissolved in it. Some of these differences were tolerated as the result of the analyst's choice of procedures, and others could be

${ }^{28}$ Granville, op. cit., note 8 above, vol. 1, pp. 163-4.

29 Rees Cyclopedia, 1818, s.v. "water"; Saunders, op. cit., note 15 above, p. ix; British Cyclopedia of the Arts and Sciences (1835), s.v. “water", vol. 2, p. 892. 


\section{The legitimization of English spas}

ascribed to the ongoing progress of science; the most recent analyst having the privilege both of being shocked at the quite different analyses his predecessors had obtained and of respectfully dismissing their results as the well-meaning blunders of those unfortunate enough to have had to live in the benighted past. Usually, however, such appeals were appeals in principle only, and their authors rarely made the attempt actually to explain how the particular discrepancies arose. ${ }^{30}$ Finally, the list of substances known to chemistry was itself increasing rapidly during the period, and while it was tempting to claim that the chemistry of one's own time was finally complete, that argument was by the late 1820s a hard one to sustain, at least for the more modest chemists. ${ }^{31}$

None of these factors alone was sufficient grounds for questioning the relevance of chemistry to the assessment of mineral waters. They were and had long been the stuff of dispute within chemistry, the arguments used by chemists to show the superiority of their work over that of other chemists, and not only could they be tolerated, but even regarded positively as a sign of the critical minds of chemists and the progress of their science. What emerged between 1815 and 1835 was something deeper, a growing scepticism from within chemistry itself about the validity of chemical knowledge and a corresponding need to reconsider and revise the arguments for the applicability of chemistry to mineral waters.

The most serious threat to the chemists' confidence came as a result of theoretical discussions about the likely state of salts in dilute aqueous solutions, the problem that was at the heart of mineral water analysis. For the most part mineral water chemists had been concerned with compounds, with the salts dissolved in a water. Especially in the wake of Bergman, they had assumed that the water itself was mainly a vehicle, dissolving compounds from the bedrock, bringing them to parts of the body where their medicinal powers were made manifest. The acids and bases that made up these compounds could be determined by indicators, and the salts themselves worked out by utilizing the principles of affinity that had been developed in the first half of the eighteenth century. In 1815 Dr John Murray, a Scottish physician-chemist, author of chemistry textbooks, and extra-mural lecturer in chemistry and materia medica at Edinburgh, proposed that there was good reason to think that the set of salts chemists discovered on analysis was neither the set of salts that existed in the water nor bore any definite relation to the salts the patient drank. ${ }^{32}$ Chemistry might be a wholly unsatisfactory guide to composition, since a rearrangement of acids and bases into different salts might occur during analysis, leaving the analyst with an incorrect notion of which salts were actually in the water.

Murray grounded his proposal in arguments drawn from medicine, chemical theory, and what for lack of a better term we may call the philosophy of science. The

\footnotetext{
${ }^{30}$ Granville, op. cit., note 8 above, vol. 2, pp. 405-9; Thornton J. Herapeth and William Herapeth, 'On the waters of the Dead Sea', J. Chem. Soc., 1849, 2: 338-9.

${ }^{31}$ Charles Cuff, 'On the presence of iodine, potash, and magnesia in the Bath waters', Philos. Mag., 2nd ser. 1830, 7: 9-10.

32 John Murray, 'An analysis of the mineral waters of Dunblane and Pitcaithly; with general observations on the analysis of mineral waters, and the composition of Bath water', Ann. Philos., 1815, 6: 256-69, 347-63; idem, 'A general formula for the analysis of mineral waters', ibid., 1817, 10: 169-77; 'Murray, John', DNB.
} 


\section{Christopher Hamlin}

medical argument presented the familiar problem of a discrepancy between medical and chemical evidence, cases of waters that appeared to have medical properties but whose constituents, especially earths like calcium carbonate, were inconsistent with those properties. Murray had himself faced such a discrepancy. Asked to analyse springs at Dunblane and Pitcaithly in the Grampians, he found nothing to account for their purgative effects. ${ }^{33}$ A closely associated problem had vexed those trying to make synthetic mineral waters on the basis of analyses of natural waters, for they often found themselves unable to get the barely soluble constituents disclosed by the analysis to dissolve.

Murray found a plausible explanation for both anomalies in the theories of the dissolved state advanced by the French chemist C. L. Berthollet. Berthollet argued that the rules of affinity provided far too simplistic a picture of the set of salts that would form from any given combination of acids and bases in an aqueous solution. According to these rules, the strongest acid and base would combine until they had fully neutralized one another, and any excess would then go on to saturate the next strongest partner, and so on. Berthollet and Murray held that affinity was only one of many factors affecting the salts that would exist. All possible combinations would probably exist, at least to some degree, with the proportions among them varying in accord with changes in the physical conditions of the water. ${ }^{34}$ Hence the changes that occurred in the process of analysis, whether through the addition of reagents or the evaporation of the aqueous solvent to induce crystallization (both central parts of Bergman's standard method), might be expected to change the composition of the water. Berthollet was the more radical on this issue, holding that all manner of physical conditions - temperature, pressure, dilution factor-would affect a delicate equilibrium, while Murray took the view that in dilute solutions such as mineral waters the most soluble set of salts was likely to be the one truly present in the water. ${ }^{35}$ In both cases, however, water was something more than a vehicle for conveying stable substances from the body of the earth to the human body. While neither chemist anticipated the modern view of the dissolved state in which water is actively in chemical combination with acidic or basic ions, both recognized that a great and inaccessible amount of rearrangement of chemical species could go on in the dissolved state, so that what one found on analysis might be quite different from what was in the unanalysed water.

Murray's third argument was that there were fundamental philosophical reasons that would prevent us from ever learning the composition of the natural water. The problem he raised appears in many guises in the modern philosophy of science, ranging from Heisenberg's uncertainty principle to the various anthropic cosmological principles. Can we ever show that our observations do not change that which we are observing, wondered Murray, and he answered the question in the negative. In analysis one altered conditions and it could never be shown that the

\footnotetext{
${ }^{33}$ Murray, 'Dunblane', op. cit., note 32 above, p. 265.

34 Idem, Elements of chemistry, 2 vols., Edinburgh, William Creech, 1810, vol. 1, pp. 31-50.

${ }^{35}$ Murray, 'Dunblane', op. cit., note 32 above, p. 350; J. Berzelius, 'Examen chimique des eaux de Carlsbade, de Toplitz, et de Königswart', Anns Chim. Phys., 2nd ser., 1825, 28: 258-60.
} 


\section{The legitimization of English spas}

analytical intervention did not alter composition, since any attempt to prove that would itself be another intervention subject to the same criticism. ${ }^{36}$

In practice Murray backed away from some of these implications. Though he held that one could never say for certain what combination of salts existed in solution, he argued that an arrangement based on maximum solubility was more consistent with what was known of medical effects than the usual arrangement in terms of affinity. Accordingly, he suggested that chemists offer their clients three sets of results: the individual acids and bases (all that we could really claim to know, in Murray's view), their arrangement into compounds on the basis of affinity (to allow comparison with prior analyses), and their arrangement according to the maximum solubility criterion, the form in which they probably existed. ${ }^{37}$

The chemists' response to Murray illustrates social changes that were taking place in chemistry as a profession, which would have great impact over how the practice of mineral water analysis would subsequently be dealt with. Murray himself was only marginally involved as a practising, fee-for-service analyst; mainly he was an academic, living by lectures and texts. Yet his arguments had great potential to threaten the livelihood of practising chemists, for he was insisting that their chief stock-in-trade, a list of the salts in a mineral water, was in fact not an empirically available piece of knowledge. Nevertheless, for the most part chemists did accept his arguments. His explanations of the embarrassing inconsistency between analysis and medical properties and of the failure of analyses to provide a satisfactory basis for syntheses were by far the most plausible resolutions to problems that must have discomfited a great many mineral water chemists.

Yet they did not follow Murray in admitting the uncertain nature of their analytical findings; instead, they found refuge in a double standard. As chemists they accepted the force of Murray's arguments, as analysts of mineral springs they retained the old Bergmanian conventions. There were attempts to justify such conduct by righteously asserting that what was most important medically was that analyses be done in a common manner so that users would be able to compare one spring against another. "A uniform and comparable arrangement of results is of such primary importance, that the choice of the principle to be adopted is of less moment" wrote F. A. Abel and Thomas Rowney, students of the Royal College of Chemistry in $1848 .{ }^{38}$ Yet the apology is a bit strained; Abel and Rowney could not quite escape the admission that unlike the Bergmanian analyst, they were no longer claiming to sell truth, but only a redefinition of a water in terms of a potentially valuable but ultimately arbitrary social convention.

That there was not greater pressure to dismiss Murray's arguments was due to the emergence of chemistry as a profession in its own right, rather than as a collection of medical and technological services that chemists offered for sale. During the early nineteenth century chemistry was growing rapidly in importance, a result of the spread of the French chemistry of Lavoisier, the launching of the heavy chemicals

\footnotetext{
${ }^{36}$ Murray, 'Dunblane', op. cit., note 32 above, pp. 349, 354.

${ }^{37}$ Idem, 'General Formula', op. cit., note 32 above, p. 174.

${ }^{38}$ F. A. Abel and Thomas Rowney, 'On the mineral waters of Cheltenham', J. chem. Soc., 1848, 1: 193-4.
} 


\section{Christopher Hamlin}

industry, the discovery through electrochemistry of numerous new elements, and not least important, the promotional efforts of leading chemists. With far more unanimity in methods and concepts, and growing loyalty to the profession, chemists were able to promote the idea that mineral water assessment was inherently the business of the science of chemistry, no matter how inadequate for that purpose its capabilities might currently be.

The strength of this new professional ethos can be seen in the response of chemists to other potential threats to their ability to make authoritative mineral water analyses. Besides having to deal with Murray's assault on the epistemic foundations of their science, chemists also had to come to grips with the fact that there were many more salt-forming elements than had been known in Bergman's day: manganese, zinc, strontium, potassium, lithium, phosphoric and flouric acids, and most importantly bromine and iodine. Some of these, and especially the last, appeared to have medicinal potency in very small concentrations. These elements were discovered in such a rush at the beginning of the century that it became difficult to insist that one's analysis really was the true one, for there might be more undiscovered elements with significant medicinal properties. It was thus hard to make the argument that one's failure to discover medicinal properties in a water meant that none were present. C. G. B. Daubeny asserted in 1836 that,

to refuse to give credence to the reports given by medical men with respect to salutary or injurious effects of a particular water, merely because the chemists can discover in it no active principle, would seem a proceeding not less unphilosophical, than that of which our predecessors were guilty, in treating as fabulous accounts given of stones that had fallen from the sky, because they did not understand how such ponderous masses could have continued suspended in it. And on the other hand, granting that a spring possesses peculiar virtues, we must suppose that it differs, either in its mechanical, or chemical properties, from the rest. ${ }^{39}$

The willingness to entertain such a possibility was in effect to admit in principle that at least some and perhaps all of those doctors who had clung steadfastly to their claims of medicinal properties for certain waters in the face of ridicule from chemists might have been right. It may seem as if the chemists were surrendering their hard-won authority, yet the argument was not made by those opposed to chemistry, but by chemists who had recognized and were trying to work out a new role for chemistry that would complement rather than replace the older market for partisan analyses. In their view, mineral water analyses would be undertaken as part of systematic utilitarian inquiry of the sort envisioned by (and frequently sponsored by) the British Association for the Advancement of Science during its early years.

This view appeared clearly in Daubeny's 1836 review of the mineral water literature, but Daubeny's work was in turn founded on an 1832 treatise by Gairdner, which was in turn based on William Saunders's Treatise on the chemical history and medical powers of some of the most celebrated mineral waters of 1800 , and as a minority tradition in the mineral water literature the outlook goes back at least as far

${ }^{39}$ C. G. B. Daubeny, 'Report on the present state of our knowledge with respect to mineral and thermal waters', Sixth Report of the BAAS (Bristol, 1836), London, John Murray, 1837, pp. 15-19, 44-5. 


\section{The legitimization of English spas}

as Boyle. In all these works, authors attempted to avoid becoming entangled in the controversies over the powers of particular waters, all the while taking the analyses sufficiently seriously to make useful generalizations. They called for peace between the doctors and the chemists and for truce in the battles for legitimization between rival spa promoters. Conflict was to be postponed in favor of a massive campaign of empirical inquiry that would ultimately clear up all that was obscure regarding the content and properties of mineral waters. By taking claims of medicinal potency seriously, chemists would be led to discover new medicinal substances, and ultimately they would arrive at a pharmaceutical chemistry that really did have the power Bergman had claimed, of allowing one to distinguish the potent from the impotent.

But such progress could be achieved only by admitting the inadequacy of contemporary chemistry and this was a delicate matter. Daubeny and Gairdner made much of Murray's insights, indeed going well beyond Murray in depicting the scandalous state of the chemists' art. "We are as yet only in possession of a few hypotheses of greater or lesser plausibility", Gairdner wrote, "even after the most laborious researches, the... different combinations are often founded upon hypothetical, and even altogether arbitrary grounds. $"{ }^{40}$ Yet they were equally wary of the traditional medical arguments, Gairdner being most explicit about the need to walk the fine line:

although I assume experience to be our principal guide in judging of the real effects of any spring ... let it not be supposed that I undervalue chemical analysis, or am of the number of those who regard them [mineral springs] as specifics prepared by the Hand of Nature for the cure of the more obstinate maladies with which human nature is afflicted.

That stance, Gairdner recognized, would be tantamount to "mystical empiricism" and would constitute "an insurmountable barrier to the acquirement of any true theory of their action". 41

In modern parlance what Daubeny and Gairdner were calling for was the launching of a Baconian research programme to be carried out in the public interest and, one presumes, at the public expense. Such a programme would rationalize the use of springs, and in doing so, demonstrate the indispensability of chemistry and chemists. It was not to be exclusively a medically-oriented research programme; both Daubeny and Gairdner saw a potentially lucrative geochemical significance in mineral water analyses. The salts these springs brought to the surface were clues to the composition of subterranean rock and the information provided by analyses might, when properly ordered, lead to important knowledge of the distribution of mineral resources. ${ }^{42}$

\footnotetext{
${ }^{40}$ Meredith Gairdner, Essay on the natural history, origin, composition, and medical effects of mineral and thermal springs, Edinburgh, Blackwood, 1832, pp. 62-3, 356; Daubeny, op. cit., note 39 above, p. 48; Granville, op. cit., note 8 above, vol. 1, p. xxxi.

${ }^{41}$ Gairdner, op. cit., note 40 above, p. 357.

42 R. Kirwan, An essay on the analysis of mineral waters, London, D. Bremner, 1799, pp. 1-3; Daubeny, op. cit., note 39 above, pp. 56-75; F. A. Abel and Thomas Rowney, 'Analysis of the water of the artesian wells, Trafalgar Square', J. chem. Soc., 1848, 1 : 97.
} 


\section{Christopher Hamlin}

No publicly funded research programme of the sort Daubeny and Gairdner envisioned was undertaken. What they had done however, simply by outlining the sort of inquiry that was needed, was to bring much more of the ethos of pure scientific research into mineral water analysis where it merged with the older ethos of analysis as a service undertaken for a client. Yet the rhetoric of Baconianism too could be, and was, adopted by those chemists working in the authority-for-hire industry. The prospect of a reliable catalogue of all mineral waters to be created through a vast Baconian enterprise of fact-collecting could appeal to all, for finally the true merits of whatever spring one was defending would be recognized and the fraudulent claims of its rivals exposed. In 1808 Frederick Accum had explained his "contribution... to chemical knowledge" regarding the composition of the Cheltenham springs (surely one of the most brazenly commercial articles ever to appear in a scientific journal) in such terms. He meant "no invidious comparisons ... with other springs of a similar nature . . . Unbiassed as I stand, a humble labourer in the field of chemical science, it is merely my wish to furnish a clear idea of the nature and composition of these fountains of health." 43 Similarly, one "Amicus" writing in the Annals of Philosophy on behalf of mineral waters in Caversham, Berkshire, observed that "if a chemist could be repaid for an analyzing tour through Britain, beneficial results might ensue to the community". Unknown springs "that deserved a better fate" (like the one at Caversham) would then be vindicated. ${ }^{44}$ In such a Baconian campaign every analysis could be seen as but a further contribution to knowledge, and not as the sordid attempt to put one over on the gullible public. The variability of results even lost some of its negative character, for all contributions were grist for the Baconian mill and the inadequacies of present knowledge would automatically yield to the continuing advance of knowledge.

Kargon, and Bud and Roberts have made it clear that during the mid- to late nineteenth century chemistry came of age. ${ }^{45}$ No longer was there need to defend its utility so regularly, or to scrounge for resources on a case-by-case basis. The role of mineral water analysis in this achievement was probably not a large one, but in a sense mineral waters had come to legitimize chemistry just as chemistry had once legitimized mineral waters. Daubeny and Gairdner especially had succeeded in sketching the view of a world full of substances which chemists, organized as an independent profession and regulated by the rules of sound philosophy, would discover, understand, and find ways of utilizing.

The fall of the spa as medical institution is sometimes equated with the rise of a rational medicine in which it was possible to test reliably the results of rival therapies. Yet to the extent that chemistry was involved in this rational reappraisal, it is probably a mistake to think that progress in chemical knowledge constrained

\footnotetext{
${ }^{43} \mathrm{~F}$. Accum, 'Analysis of the lately discovered mineral waters at Cheltenham, and also of other medicinal springs in its neighbourhood', Philos. Mag., 1808, 31: 14-28.

44 Amicus, 'Analysis of the mineral waters of Caversham, Berkshire', Ann. Philos., 1816, 8: $123-4$.

45 Robert Kargon, Science in Victorian Manchester, Manchester University Press, 1977; Robert Bud and Gerrylynn K. Roberts, Science versus practice: chemistry in Victorian Britain, Manchester University Press, 1984; A. Thackray, 'The industrial revolution and the image of science', in A. Thackray and E. Mendelsohn (eds.), Science and values: patterns of tradition and change, New York, Humanities Press, 1974, pp. 3-18.
} 
controversy over mineral waters, or even played a significant part in the decline of spas by revealing once and for all that they were founded on spurious claims. Throughout the nineteenth century, chemists continued to find in mineral water analysis both a small source of income and a sign of the deserved prestige their science had achieved. Probably more so than doctors, chemists continued to believe that very many waters did have important medical properties. ${ }^{46} \mathrm{Had}$ there been social reasons to engage in controversy, the problems of solution theory raised by Murray and of the finality of chemical knowledge raised by Daubeny and Gairdner would surely have provided ample ammunition for polemics. But, for reasons that are unclear and certainly complex, doctors and patients were turning away from spas by the mid-nineteenth century, and while competition between resort towns continued to exist, the cultural relations of health to holidays had changed so much that legitimization from chemistry was no longer so decisive.

46 'Review of Adam Hunter, Treatise on the Mineral Waters of Harrowgate and its Vicinity', Lancet, $1830-1$, i: $183-4$. 